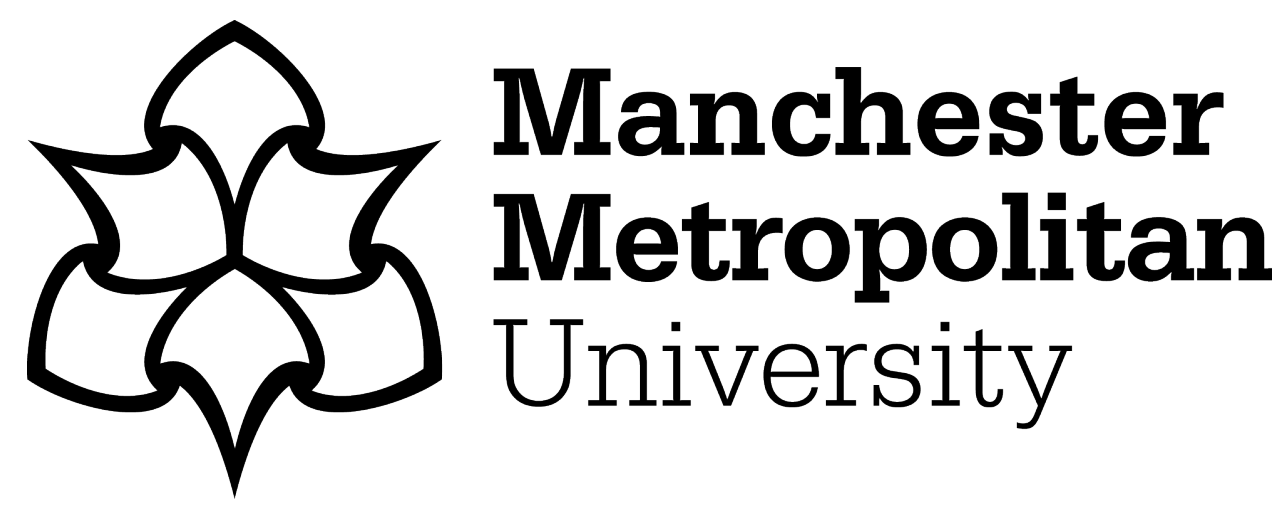

Kelly, LC, Cockell, CS, Thorsteinsson, T, Marteinsson, V and Stevenson, J (2014) Pioneer Microbial Communities of the Fimmvörðuháls Lava Flow, Eyjafjallajökull, Iceland. Microbial Ecology: an international journal, 68 (3). pp. 504-518. ISSN 0095-3628

Downloaded from: https://e-space.mmu.ac.uk/321719/

Version: Accepted Version

Publisher: Springer Verlag

DOI: https://doi.org/10.1007/s00248-014-0432-3

Please cite the published version 


\section{Pioneer microbial communities of the Fimmvörðuháls lava flow, Eyjafjallajökull,}

\section{Iceland}

Laura C Kelly ${ }^{1,2^{*}, \S}$, Charles S Cockell ${ }^{1,3^{*}}$, Thorsteinn Thorsteinsson ${ }^{4}$, Viggó Marteinsson ${ }^{5}$, John Stevenson ${ }^{6}$

${ }^{1}$ Geomicrobiology Research Group, CEPSAR, Open University, MK7 6AA, UK.

${ }^{2}$ School of Biology and Conservation Ecology, Manchester Metropolitan University, Manchester M1 5GD.

${ }^{3}$ School of Physics and Astronomy, University of Edinburgh, Edinburgh, EH9 3JZ, UK.

${ }^{4}$ Hydrology Division, National Energy Authority, Grensasvegi 9, IS-108 Reykjavik, Iceland

${ }^{5}$ Matís Idt./Food Safety, Environment \& Genetics, Vínlandsleid 12, 113 Reykjavik, Iceland.

${ }^{6}$ School of Geosciences, University of Edinburgh, Edinburgh, EH9 3Jw, UK.

* Current addresses

${ }^{\S}$ Corresponding author

Laura C Kelly, School of Biology and Conservation Ecology, Manchester Metropolitan

University, Manchester M1 5G, UKD.

Tel: +44 (0)161 2471190, Email: laurackelly@live.ie

Keywords: volcanic/basalt/pioneers/chemolithotrophs/diazotrophs/Iceland 



\begin{abstract}
Little is understood regarding the phylogeny and metabolic capabilities of the earliest colonists of volcanic rocks, yet these data are essential for understanding how life becomes established in, and interacts with the planetary crust, ultimately contributing to critical zone processes and soil formation. Here we report the use of molecular and culture-dependent methods to determine the composition of pioneer microbial communities colonising the basaltic Fimmvörðuháls lava flow at Eyjafjallajökull, Iceland, formed in 2010. Our data show that three to five months post eruption, the lava was colonized by a low-diversity microbial community dominated by Betaproteobacteria, primarily taxa related to nonphototrophic diazotrophs such as Herbaspirillum spp., and chemolithotrophs such as Thiobacillus. Although successfully cultured following enrichment, phototrophs were not abundant members of the Fimmvörðuháls communities, as revealed by molecular analysis, and phototrophy is therefore not likely to be a dominant biogeochemical process in these early successional basalt communities. These results contrast with older Icelandic lava of comparable mineralogy, in which phototrophs comprised a significant fraction of microbial communities and the non-phototrophic community fractions were dominated by Acidobacteria and Actinobacteria.
\end{abstract}




\section{INTRODUCTION}

Despite their global abundance and environmental and ecological significance, surprisingly little is known regarding the initial colonists of freshly-deposited volcanic rocks. Volcanic rocks play a significant role in the global carbonate-silicate cycle as they weather [1-5], while some of the most fertile soils in the world are of volcanic origin [6-8]. Understanding how newly-formed volcanic substrates become colonised by microbial communities, which may ultimately play a role in rock weathering, soil formation and plant ecosystem development, is an essential task in earth sciences.

The surface of unvegetated volcanic lavas are an extreme, but nevertheless viable habitat for microorganisms [9-12]. They can be subject to desiccation, exposure to UV radiation, temperature fluctuations and low organic and nitrogen availability. One of the first studies of microbial colonisation of freshly-deposited volcanic rock occurred on the island of Surtsey, Iceland, formed during the 1963-1968 volcanic eruptions off the southern Icelandic coast. These lavas provided a unique laboratory for the investigation of biological establishment and succession on newly deposited volcanic substrata. Phototrophs were already observed by 1968 [13] and subsequent culture-based and microscopy investigations reiterated the importance of chlorophytes, lichens and mosses to ecosystem development on the island [14-17]. A further study reported the presence of cyanobacteria, including Anabaena and Nostoc on the Icelandic Island of Heimaey, eighteen months after an eruption in 1973 [18].

Molecular-based studies on the microbiota of volcanic substrates have only emerged within the past few years, revealing that such habitats are capable of harbouring significant microbial diversity [11-12]. The study of a 1959 cinder deposit in Hawaii revealed a diverse community comprising Cyanobacteria, Acidobacteria and Alphaproteobacteria and the presence of organisms specifically capable of CO-oxidation [19-20]. On unvegetated volcanic substrates at the Mount St. Helens volcano, seventeen years after the eruption, 
Ibekwe et al. [9] recorded the presence Alpha- and Betaproteobacteria and Actinobacteria, while Gomez-Alvarez et al. [11] found that in Hawaiian deposits formed in 1959, microbial communities were dominated by Acidobacteria and Alphaproteobacteria, with a large percentage of unclassified sequences. Recent molecular investigations of weathered, unvegetated Icelandic volcanic rocks revealed diverse microbial communities which, although differing in composition amongst volcanic rocks of different mineralogies, contained significant proportions of Acidobacteria, Actinobacteria and Proteobacteria [12, 21]. Cyanobacteria were abundant only in volcanic glasses [12].

In the aforementioned and indeed similar molecular studies of volcanic substrates, sampling began well after the establishment of microbial communities, with the substrates in these investigations ranging in age from seventeen years [9] to material deposited circa 0.8 Mya [12, 21-22], with no current existing reports of molecular analyses of freshly-deposited volcanic material. In the present study, we sought to redress this lack of in-depth characterisation of the earliest microbial colonists of freshly-deposited volcanic substrates.

In March and April 2010, eruptions of the Eyjafjallajökull volcano in Southern Iceland produced a new lava flow of basaltic composition, the Fimmvörðuháls flow, offering an opportunity to 1) identify the earliest microbial colonists of this globally abundant geological substrate and 2) compare these microbial communities with those of previous studies of older Icelandic volcanic substrates $[10,12,21-22]$ less than $50 \mathrm{~km}$ away. In particular, we sought to test the hypothesis, using a combination of molecular and cultivation-dependent methods, that phototrophs are abundant colonists on the newly-available habitat offered by volcanic eruptions.

\section{MATERIALS AND METHODS}




\section{Field site and sampling}

Samples were collected from the Fimmvörðuháls lava flow, which was erupted from the Eyjafjallajökull volcano between 20 March and 12 April 2010 from the Magni and Móði craters (Fig. 1). The flow is located between the Eyjafjallajökull and Mýrdalsjökull glaciers in southern Iceland and comprises mildly alkalic olivine basalt lava $(<2 \%$ phenocrysts of olivine, plagioclase and clinopyroxene; [23], forming lobes that cover an area of $1.3 \mathrm{~km}^{2}$ with an average thickness of 10-20 m (estimated volume: 20 million cubic metres; [24]).

On 5 July 2010, nine readily accessible sampling sites (named 1-9) were established on the lava flow. The sites were located in three loose clusters of three along a transect, relatively close to the source of the flow, as shown in Fig. 1. The maximum distance between clusters was $0.48 \mathrm{~km}$. The sampling sites described in this study are located within the area delineated by coordinates $63^{\circ} 38^{\prime} 13.20^{\prime \prime} \mathrm{N}, 19^{\circ} 27^{\prime} 1.08^{\prime \prime} \mathrm{W}$ and $63^{\circ} 38^{\prime} 23.10^{\prime \prime} \mathrm{N}, 19^{\circ} 26^{\prime} 31.80^{\prime \prime} \mathrm{W}$. Replicate (three) samples of lava, weighing approximately 60-250 g, were taken from each site. The maximum distance between replicates was approximately $2 \mathrm{~m}$. Further samples were taken on 31 August 2010 from the same sites.

The samples, taken from the surface of the lava flow, comprised the lava and associated eruption ash deposits contained within the fractures and pore spaces. Samples, removed using a rock hammer sterilized in ethanol, were broken directly into sterile plastic bags (Whirlpak, Fisher Scientific, UK) without handling, double bagged and boxed immediately after collection. Samples were frozen for molecular analysis $\left(-20^{\circ} \mathrm{C}\right)$, or subjected to culture-based analyses following collection. Additional samples of lava from each site were fixed in $2 \%$ formaldehyde for subsequent cell counts. Samples were labelled according to the month ( $\mathrm{J}$ - July or A - August), site of retrieval and replicate number. 


\section{Geochemical analyses}

Whole-rock major and minor element compositions were obtained using an ARL 8420+ dual goniometer wavelength-dispersive X-ray fluorescence (XRF) spectrometer (Thermo Scientific, USA). XRF analysis was carried out on glass discs (major element concentrations) prepared by fusing one part finely powdered lava sample, with five parts of FluXana flux (20\% lithium tetraborate/80\% lithium metaborate mix) [25], or on pressed powder pellets (trace elemental compositions) [26]. Four individual samples from each of the nine sampling sites were analysed.

Three finely-ground $25 \mathrm{mg}$ samplesfrom each site in July were examined for their nitrogen, organic carbon and total sulfur concentrations. Carbon content was determined using a Europa ANCA-SL elemental analyser coupled to a continuous flow mass spectrometer (Europa GEO 20-20, Knutsford, UK) with a detection limit of $0.001 \%$. Nitrogen analysis was carried out using a Carlo Erba NA2500 Elemental Analyser (Glasgow, Scotland) with a detection limit of $0.001 \%$. Sulfur was measured using a LECO SC 444 (St. Joseph, MI, USA) instrument with a detection limit of $0.001 \%$.

\section{Direct isolations and enrichment cultures}

To test for the presence of certain functional microbial groups, we attempted their direct isolation in the laboratory using samples from sites 1, 5 and 9. Unless otherwise stated, all samples from these sites and sampling period were processed identically. Subsamples of lava were crushed to a maximum size of $1 \mathrm{~cm}$ under sterile conditions in a laminar flow hood and shaken at $100 \mathrm{rpm}$ at $21{ }^{\circ} \mathrm{C}$ for $1.5 \mathrm{~h}$ in $10 \mathrm{~mL}$ double distilled $\mathrm{H}_{2} \mathrm{O}$, before plating onto solid media (100 $\mu \mathrm{L}$ undiluted sample), or inoculating into $20 \mathrm{~mL}$ of liquid media (500 $\mu \mathrm{L}$ plus fragments). 
To test for the presence of phototrophs, samples were incubated in BG11 broth (pH 7.2) [27] for enrichment. Chemolithotrophs capable of oxidising sulfur were enriched in sulfur-oxidizers (SOX) broth $(\mathrm{pH}$ 7.0-7.2) [28]. The presence of nitrogen-fixing organisms in samples collected in August 2010 was tested using nitrogen-free Norris agar (pH 7.2) [29], prepared using $1.5 \%$ Noble agar. Plates and broths were incubated at room temperature $\left(21^{\circ} \mathrm{C}\right)$. Following 46 days growth in broth, cultures were plated in duplicate $(100 \mu \mathrm{L})$ onto the corresponding solid media for isolation. Solid BG11 and SOX plates contained 2\% Noble agar. BG11 broths and plates were incubated under natural light conditions. Solid media incubations were for 10-14 days. To test for the presence of heterotrophs, organisms were isolated on two solid media; nutrient agar (Oxoid, Fisher Scientific, UK) (pH 7.3 - 7.4) and a 1/100 nutrient agar ( $\mathrm{pH}$ 6.7) prepared with 2\% Noble agar (BD Biosciences, UK).

\section{Identification of isolates}

Colonies representative of the dominant morphologies present in each sample, in addition to a selection of some of the less common morphologies observed on the various media, were subcultured three to six times to obtain pure cultures. Selected bacterial isolates were subjected to colony PCR with universal eubacterial primers $\mathrm{pA}$ and $\mathrm{pH}$ [30-32] to amplify almost complete 16S rRNA genes, or in the case of cyanobacteria, pA and CYA781R [33], amplifying partial 16S rRNA genes. Primers $817 \mathrm{f}$ and 1536r [34] were used to amplify partial $18 \mathrm{~S}$ genes from selected fungal isolates. Each $50 \mu \mathrm{L}$ reaction mixture contained $0.2 \mu \mathrm{M}$ each primer, $200 \mu \mathrm{M}$ each dNTP (New England Biolabs, UK), 2.5 U Taq DNA polymerase, $2 \mathrm{mM}$ $\mathrm{MgCl}_{2}$ and 1X PCR buffer (200mM Tris- $\left.\mathrm{HCl}(\mathrm{pH} 8.4), 500 \mathrm{mM} \mathrm{KCl}\right)$ (Invitrogen Corporation, UK). Amplifications were performed in a G-Storm GS1 thermal cycler (GRI Ltd., UK), with an initial denaturation at $94{ }^{\circ} \mathrm{C}$ for $5 \mathrm{~min}$, followed by thirty-five cycles of 94 ${ }^{\circ} \mathrm{C}$ for $1 \mathrm{~min}, 55^{\circ} \mathrm{C}$ for $40 \mathrm{~s}$ and $72^{\circ} \mathrm{C}$ for $40 \mathrm{~s}$, with a final extension for $10 \mathrm{~min}$ at $72{ }^{\circ} \mathrm{C}$. 
Sequencing of Bacteria and phototrophs was performed with pA. In instances where these sequences suggested new species, additional sequencing with com1 (as a forward primer) [35] and/or $\mathrm{pH}$ was performed (Mclab, USA or GATC Biotech, Germany) to provide a more complete gene sequence of at least $1 \mathrm{~kb}$.

\section{Direct cell counts}

Microbial numbers were calculated per gram of dry weight of lava. Counts were performed on all replicate samples from sites 1,5 and 9. To enumerate microbes, $100 \mu \mathrm{L}$ of dd $\mathrm{H}_{2} \mathrm{O}$ containing powdered lava (approximately 0.01 to $0.04 \mathrm{~g}$, crushed as described below) was added to $900 \mu \mathrm{L}$ of $\mathrm{ddH}_{2} \mathrm{O}$ and $100 \mu \mathrm{L}$ of a solution of $1 \mathrm{X} \mathrm{SYBR}^{\circledR}$ Green I DNA binding dye according to the manufacturer's instructions (Invitrogen, UK). The solution was vacuum filtered onto black $0.2 \mu \mathrm{m}$ Nuclepore polycarbonate filters (Whatman, UK). Microorganisms were enumerated under at least 30 fields of view on a Leica DMRP fluorescence microscope (Leica Microsystems, Germany) using an excitation waveband of 450-490 nm (Leica filter cube I3) and an emission long band cutoff filter of $>515 \mathrm{~nm}$. A two way analysis of variance (ANOVA) was performed on the data in Microsoft Excel.

\section{DNA extraction}

DNA was extracted from all samples from site 5 and one random chosen sample each from sites 1 and 9 at each sampling period. Lava was crushed to a powder in a laminar flow hood using a sterilized metal container and plunger as described previously [36]. Total DNA was extracted from all samples ( 10 g each), using a PowerMax Soil DNA Isolation Kit (MoBio Laboratories, UK). Extraction was performed according to manufacturer's instructions, with the exception of an extended incubation period of $2.5 \mathrm{~h}$ after the addition of buffer $\mathrm{C} 2$ 
(designed for the removal of PCR inhibitors), and a $1 \mathrm{~mL}$ elution volume. DNA was quantified, in triplicate, by NanoDrop.

\section{Bacteria 16S rRNA gene clone libraries}

Amplification of 16S rRNA genes from basalt communities was performed with universal

eubacterial primers $\mathrm{pA}$ and $\mathrm{pH}$, and products purified before cloning into the $\mathrm{pCR} 4{ }^{\circledR}$ vector as previously described [12]. Inserts were sequenced with pA (GATC Biotech, Germany). Chimera detection was performed through greengenes [37]. Following chimera removal, all libraries were normalised to that containing the smallest number of sequences. Sequences were aligned over E. coli nucleotide positions 100 - 785 in MOTHUR (version 1.25.1) [38] against the greengenes core database set, and a distance matrix generated in Phylip [39] (version 3.6). This distance matrix was used in MOTHUR to group sequences into operational taxonomic units (OTUs) at 97\% sequence identities. Following MOTHUR normalisation, richness and diversity estimates were calculated, and samples compared by Libshuff [40] using MOTHURr, and principal component analysis (PCA) using PRIMER 5 (version 5.2.0). Classification of clones was performed through the RDP [41] (release 10). Sequences representative of each OTU were also searched against those deposited in GenBank, through the NCBI blastn program, revealing the closest cultured and uncultured sequences.

\section{Comparison of isolates and 16s rRNA gene clones}

16S rRNA gene sequences from both isolates and clone libraries were aligned over E. coli nucleotide positions $134-730$ and OTUs generated in MOTHUR at 97\% sequence identities, as described above. Using these data, a bootstrapped (1000 iterations) NeighborJoining phylogenetic tree was constructed with MEGA4 [42] using representative sequences 
from each OTU and related GenBank sequences from cultured and uncultured organisms. The process was repeated with the same sequences to generate a Maximum Likelihood tree.

\section{RESULTS}

\section{Geochemical analyses}

Average elemental compositions of lava from the nine sampling sites were as follows [equivalent oxide, mean (standard deviation)]: $\mathrm{SiO}_{2}, 47.37(0.90) ; \mathrm{Al}_{2} \mathrm{O}_{3}, 14.88(0.17) ; \mathrm{Fe}_{2} \mathrm{O}_{3}$, 13.29 (0.34); $\mathrm{MgO}, 8.11$ (0.39); $\mathrm{CaO}, 9.50$ (0.39); $\mathrm{Na}_{2} \mathrm{O}, 2.83$ (0.27); $\mathrm{K}_{2} \mathrm{O}, 0.72$ (0.12); $\mathrm{TiO}_{2}$, 2.90 (0.15); $\mathrm{MnO}, 0.19(0.01) ; \mathrm{P}_{2} \mathrm{O}_{5}, 0.39$ (0.01); total, $99.71(0.35)$ These data show that the lava samples were of a basaltic composition according to the Total Alkali Silica (TAS) classification scheme of igneous rocks [43], having a mean $\mathrm{Na}_{2} \mathrm{O}+\mathrm{K}_{2} \mathrm{O}$ content of $3.55 \%$. These data are in agreement with Sigmundsson et al. [23].

Nitrogen was below detection using the method employed in all the samples analysed. The organic carbon content of the samples was determined to be less than $0.001 \%$ wt. The total sulfur concentration in all of the samples examined was $0.021 \%( \pm 0.014) \mathrm{wt}$.

\section{Identification of isolates}

The identities of isolates relative to the closest $16 \mathrm{~S}$ or $18 \mathrm{~S}$ rRNA gene sequences of cultured organisms (GenBank deposits), are given in Table 1. Bacterial isolates were primarily members of the Actinobacteria and Proteobacteria phyla. Isolated fungi were members of the Ascomycota. Many bacterial isolates shared the greatest sequence identity with uncultured organisms from a variety of sources, many of these from Antarctic environments, glaciers and freshwater habitats. Among the isolates was a taxon represented by four isolates and displaying a maximum of $92 \%$ sequence identity (16S rRNA genes) to any sequence currently deposited in public databases. The closest cultured relatives of this taxon are Alicyclobacillus 
spp., members of the phylum Firmicutes, and include an isolate from Antarctic geothermal soil (AJ607430). All isolate 16Sr RNA gene sequences have been deposited in GenBank under accession numbers JF417993 to JF418153 and JF706699 to JF706701.

\section{Direct cell counts}

The average cell counts (with standard deviations) for lava samples from July and August, per g of material dry weight, were $1.58 \times 10^{6}\left(1.27 \times 10^{6}\right)$ and $2.58 \times 10^{6}\left(2.15 \times 10^{6}\right)$, respectively. Averages for the individual sites, for each season, are given in Fig. 2. A two way ANOVA indicated a significant difference in counts among sites $(\mathrm{P}=0.009)$, while no seasonal effect of season was observed $(\mathrm{P}=0.138)$.

\section{DNA extraction}

Concentrations of DNA (ng/ $\mu$ ) in extracted samples from July and August (respectively) were as follows: site 1 (5.4 and 4.2), site $5(4.4,4.2,4.7$ and 4.0, 4.5, 5.0) and site 9 (4.7 and 4.0). Subsequent $1 \mathrm{ml}$ elutions from the DNA extraction filters (see above) resulted in addition DNA recovery (not shown).

\section{Bacteria 16S rRNA gene clone libraries}

Upon removal of chimeras (an average of $2.8 \%$ of sequences) up to 106 clone sequences remained in each library. However, for the purpose of meaningful comparisions, and statistical analyses, samples were randomly normalized to the smallest library, containing 82 clones.

Diversity and richness of Fimmvörðuháls bacterial communities was low (Fig. 3), as determined at 97\% sequence identities (OTUs). The recovery of OTUs reached or approached saturation using $<100$ clones (not shown) andcoverage estimates for samples ranged from 87 
to $99 \%$. Shannon diversity indices ranged from 1.40 to 2.49 (average 2.07 ), while Chao1 [44] richness ranged from 8.0 to 46.5 (average 24.5 ).

Sixty-three individual OTUs (97\% sequence identities) were identified amongst normalised libraries. The identities of the two most abundant OTUs in each library, accounting for nine OTUs due to shared OTUs between samples, are given in Table 2, relative to the nearest cultured and uncultured sequences deposited in GenBank. Together these OTUs accounted for almost $82 \%$ of sequenced clones and individually accounted for 2.0 $-29.7 \%$ of clones among all libraries. The most abundant library OTU (OTU63), accounting for up to $9.4-48 \%$ of sequences per library, was identified as belonging to the genus Herbaspirillum, a group known to possess diazotrophic members, while OTU59 and OTU54 (together accounting for $16.1 \%$ of sequences, were likewise affiliated with known nitrogenfixing genera. OTU45 and OTU49, together accounting for $13.9 \%$ of library sequences, were affiliated with iron and $\mathrm{H}_{2}$ oxiders, and OTU38 with a known sulfur-oxidizing chemolithotroph, Sulfuricurvum (Table 2). The remaining fifty-four library OTUs identified accounted for $0.3 \%$ of library clones on average (range $0.1-1.4 \%$ ), and were affiliated with sequences recovered from a variety of habitats, particularly glacial and soil environments (not shown) and most closely related to taxa known for nitrogen-fixing and chemolithotrophic nutrition. Among the sixty-three identified clone OTUs, 52\% were unique to one sample and were mostly representative of one or two clones. Clone 16S rRNA gene sequences have been deposited in GenBank under accession numbers HQ898914 to HQ900366.

Phylum Proteobacteria sequences and the Betaproteobacteria in particular, were numerically dominant in all libraries. The Betaproteobacteria comprised $57.7-97.1 \%$ of clones in each library (and 70\% of sequenced clones combined) while Epsilonproteobacteria also contributed significantly $(22-29 \%)$ to a number of samples (Fig. 4), corresponding to OTU38 described above. Despite the numerical dominance of Betaproteobacteria sequences 
in all samples, Libshuff analysis comparing individual samples revealed significant differences in clone library composition, both within and between sampling sites. Sample pairings for which non-significant differences were observed are given in Supplementary Table S2. PCA performed on libraries also revealed variability among samples, with one sample from site 5 in July particularly different from all others, separated along the first component axis (Supplemental Material). The two principal components shown together accounted for $42.3 \%$ of the variability observed among lava samples.

\section{Identification of cultured species also contained within clone libraries}

Following alignment of isolate and clone 16S rRNA gene sequences, ninety-two OTUs were identified at 97\% sequence identity, including twenty-eight represented by isolates only. Among these isolate-only OTUs, two were identified as Arthrobacter (represented by twenty-seven and seven isolates), most closely matching sequences from Svalbard soil (Arctic) and Livingston Island (Antarctica), respectively. A Sphingobacterium OTU was represented by 12 isolates most similar to sequences from temperate grassland (Fig. 4a). Other OTUs represented solely by isolates were affiliated with the genera Rhizobium, Variovorax, Thiobacillus and Firmicutes. Nine OTUs were represented by both clone and isolate sequences, including four of the abundant library OTUs (OTUs 49, 54, 60 and 63) described in Table 2. The most abundant OTU, affiliated with the genus Herbaspirillum and corresponding to OTU63 of clone libraries, comprised 282 clone and 10 isolate sequences. Other OTUs, their abundance in libraries and among isolate sequences and their phylogenetic affiliations are shown in Fig. 4. 


\section{DISCUSSION}

The eruption of the basaltic Fimmvörðuháls lava flow from the Eyjafjallajökull volcano in southern Iceland, during March and April 2010, provided an opportunity to investigate the colonisation of fresh lava in the immediate aftermath of the eruptions. While investigations of colonists of newly deposited Icelandic lava has been previously undertaken on the island of Surtsey [13 - 17], revealing an abundance of phototrophs, our study is the first to undertake such a detailed analyses of lava flow microbial communities at such an early stage of colonisation. We sampled the lava flow on two occasions within the first three to five months post eruption, employing both traditional culture-based techniques in concert with molecular methods to characterise the pioneer bacterial inhabitants.

Contrary to our expectations based on Surtsey reports, both our molecular and culturebased results revealed that the early microbial colonists of the Fimmvörðuháls lava flow were not composed primarily of phototrophs but rather by organisms, primarily Betaproteobacteria, affiliated with known diazotrophs, chemolithotrophs and heterotrophs. Unlike other studies which have shown the abundance of phototrophs in early successional volcanic materials [18] and deglaciated soils $[45,46]$ and inferred the important role of phototrophs in the establishment of pioneer communities, we recovered only a few phototroph-related sequences from our clone libraries and only succeeded in isolating cyanobacteria or diatoms following prior enrichment. Early reports from Surtsey detected mosses, lichens and algae by microscopy and culture-based approaches [16, 17, 47]. However, these observations were generally made on substrata at least a few years postdeposition, rather than within months as in the present study, and methodological limitations precluded a detailed community molecular analysis. In contrast, our data show that while phototrophs were present in Fimmvörðuháls communities at the very early stages of basalt 
colonization, they represented only a negligible proportion of the molecular diversity of organisms on the lava.

While our approach does not allow us to unequivocally prove the in-situ activities of isolated organisms or of taxa observed within 16S rRNA gene clone libraries, the abundance in each sample community of taxa affiliated with chemolithotrophs, heterotrophs and nitrogen-fixers, together with the available information regarding carbon, nitrogen and sulfur content of samples and the paucity of phototrophs, suggests that an early stage of chemolithotrophy and heterotrophy precedes an important role for phototrophs within the Fimmvörðuháls flow.

The accumulation of nitrogen in early primary successional environments can be a limiting factor in ecosystem development $[46,48-50]$ and nitrogen-fixing microorganisms are therefore often abundant colonizers in nitrogen-deficient terrestrial habitats [51]. Increases in nitrogen availability facilitate colonization by later successional species $[48,51]$. Nitrogen was below detection in the Fimmvörðuháls lava flow following the eruptions, thus making diazotrophy a potentially important requirement for early pioneers in the nitrogen-limited basalt. The isolation of a diversity of nitrogen-fixing organisms on nitrogen-free agar plates, together with the abundance of library 16S rRNA gene sequences affiliated with diazotrophic taxa, suggests that diazotrophy was represented in phylogenetically diverse organisms.

Despite the low organic carbon content, the lava flow hosted a diversity of heterotrophs. We hypothesise that the Fimmvörðuháls heterotrophs may have used either organic carbon derived from chemolithotrophic metabolism within the lava, and/or the airborne input of low amounts of atmospheric organic carbon compounds [52]. Atmospheric inputs of microbes may also contribute to the organic carbon pool, via cell lysis and recycling of organic cellular constitutents. Taxa we isolated in the laboratory included representatives of the Actinobacteria (Arthrobacter), Alphaproteobacteria (Sphingomonas) and many 
Betaproteobacteria including Polaromonas, Variovorax (Comamonadaceae) and Duganella, Herbaspirillum and Massilia (Oxalobacteraceae) species. These data are consistent with molecular sequencing data, which also revealed many heterotrophic Betaproteobacteria. The most abundant OTU was affiliated with Herbaspirillum, a genus which has previously been reported from 22-year-old volcanic deposits in Miyake-jima Island, Japan [53] and is known to contain representatives capable of growth under oligotrophic conditions.

Substrates supporting potential chemolithotrophic metabolism within the Fimmvörðuháls lava could have included the reduced iron available in basalt minerals such as olivines (detected as total iron in XRF data). Sulfur was also detected in our samples and exhalations of sulfur gases was shown to have occurred during the eruptions [54]. Chemolithotrophic potential within the Fimmvörðuháls lava is suggested by the isolation sulfur-oxidising Thiobacilli, and multiple independent isolations of a novel taxon on SOX media which failed to grow in the absence of thiosulfate. Furthermore, clone library OTUs affiliated with Thiobacillus and Rhodoferax were observedand an abundant OTU affiliated with the facultatively anaerobic genus Sulfuricurvum was particularly abundant in samples three months after the eruption, constituting up to $30 \%$ of clones. These data suggest the presence of other uncultured chemolithotrophic organisms capable of metabolising sulfur and/or iron.

Compared to older ( 1,750 yrs old), weathered crystalline Icelandic lava of comparable mineralogy previously studied [21], where microbial numbers were of the same order of magnitude as in the present study, the diversity and richness of bacterial communities within Fimmvörðuháls lavas, as determined by community 16S rRNA gene clone library analysis, were substantially lower. The Chao1 [44] and Shannon values we obtained were 24.5 and 2.07 , as compared to 165 and 4.04 at the same sequence similarity cutoff $(97 \%)$ on the older Icelandic basaltic lava flow [21] less than $50 \mathrm{~km}$ away. Low species diversity in 
Fimmvörðuháls lava is not surprising given the very short time available for colonisation and community development. Diversity in successional communities from other environments has been observed to increase over time. For example, the Shannon index on newly exposed glacial forefields in Peru increased from 0.8 in newly exposed material to above 4.5 for 500 year old soils [44]. Increases in species richness have been observed in Arctic glacial soils covering a 150-yr time span [55]. Site 5, located to the south west of the Módi crater (Fig. 1), is closest to the craters; perhaps close enough that the elevation of Módi may provide some shelter to site 5 , resulting in a reduced input of airborn microbes from the wind and a comparatively lower cell count from samples from this site.

The bacterial community composition of the newly colonised Fimmvörðuháls basalt, , being dominated by Betaproteobacteria, contrasts with that of older Icelandic rocks. Ancient Icelandic crystalline lava of basaltic and rhyolitic composition $(\sim 1,750 \mathrm{yrs}$ old $)$, analysed in the same manner as the present study, were dominated by Actinobacteria and Acidobacteria and harboured many other phyla, including Cyanobacteria and difficult-to-culture phyla such as Verrucomicrobia and Gemmatimonadetes. All of these rocks contained less than 5\% Betaproteobacteria [21]. Similar results were reported for ancient Icelandic volcanic glasses [12]. While the Fimmvörðuháls flow was dominated by Betaproteobacteria, community variations were observed among samples, indicating community heterogeneity on small spatial scales, similarly to the ancient basalts. Such small-scale heterogeneity was also observed in weathered Icelandic lavas [12, 21].

Many of our isolates, including some of the most numerous species, remained undetected in clone libraries. Considering the high library coverage achieved by sequencing, and the use of the same primer set for both isolate identification and library construction, failure to detect isolated species within libraries may be due to incomplete extraction of community DNA, particularly in the case of sporulating species of Arthrobacter and 
Firmicutes, and/or that cultivation resulted in significant bias towards rare organisms.

Culturable fungi, which increased in abundance in August, could not be detected by fungalspecific PCR of community DNA and attempts to detect Archaea by molecular methods (FISH and PCR) also proved unsuccessful (not shown). Despite optimisation of a PCR protocol to detect algal $18 \mathrm{~S}$ rRNA genes, we did not detect algae in our community DNA extracts (not shown), further evidence that despite their presence in many samples, as detected by enrichment culture, the abundance of algae was very low.

In conclusion, our data show that three to five months post deposition, the Fimmvörðuháls lava flow contained microbial communities characterized by low diversity and abundant Betaproteobacteria affiliated with diazotrophic, heterotrophic and chemolithotrophic taxa. Our observations show that even three months after their eruption, lava flows may be host to functionally distinct microbial communities of low diversity. Some of the most abundant OTUs observed in these samples could not be affiliated to a genus, evidence that the newly lava flows harbour novel organisms with unknown contributions to early biogeochemical cycles. We conclude that potentially biogeochemically active communities were established remarkably quickly after the Fimmvörðuháls eruptions and that future studies of primary succession on such volcanic materials must begin within days and months after the appearance of the new habitat.

\section{Acknowledgements}

This research was supported by a Natural Environment Research Council grant (NERC;NE/I007695/1. LiDAR data were collected on NERC Airborne Research and Survey Facility flight UR10/02. The open source GMT (Wessel and Smith, 1991) and GRASS GIS (Neteler et al., 2012) software packages were used in LiDAR processing. We thank Stephen 
Summers (Dept. of Physical Sciences, Open University, UK) for assistance with July sampling.

\section{References}

[1] Berner RA (1993) Weathering and its effect on atmospheric $\mathrm{CO}_{2}$ over Phanerozoic time. Chem Geol 107:373-374. doi:10.1016/0009-2541(93)90212-2

[2] Gaillardet J, Dupre P, Louvat CJ, Allègre CJ (1999) Global silicate weathering and $\mathrm{CO}_{2}$ consumption rates deduced from the chemistry of the large rivers. Chem Geol 159:3-30. doi:10.1016/S0009-2541(99)00031-5

[3] Dessert C, Dupre B, Francois LM (2001) Erosion of Deccan Traps determined by river geochemistry: impact on the global climate and the ${ }^{87} \mathrm{Sr} /{ }^{86} \mathrm{Sr}$ ratio of seawater. Earth Planet Sc Lett 188, 459-474. doi:10.1016/S0012-821X(01)00317-X

[4] Dessert C, Dupré B, Gaillardet J, François LM, Allègre CJ (2003) Basalt weathering laws and the impact of basalt weathering on the global carbon cycle. Chem Geol 202:257-273. doi:10.1016/j.chemgeo.2002.10.001

[5] Bland W, Rolls D (2005) Weathering: an introduction to the scientific principles. Arnold, London.

[6] Dahlgren R, Shoji S, Nanzyo M (1993) Mineralogical characteristics of volcanic ash soils. In Volcanic Ash soils Genesis, Properties, and Utilization (eds S Shoji and M Nanzyo) Elsevier, Amsterdam, pp 101-143.

[7] Vitousek PM, Ladefoged TN, Kirch PV, Hartshorn AS, Graves MW, Hotchkiss SC, Tuljapurkar S, Chadwick OA (2004) Soils, agriculture, and society in precontact Hawaii. Science 304:1665-1669. doi:10.1126/science.1099619

[8] Belobrov VP, Ovechkin SV (2005) Soils and soil cover patterns of volcanic plateaus in Indochina. Eurasian Soil Sci 38:1065-1074. 
[9] Ibekwe MA, Kennedy AC, Halvorson JJ, Yang C-H (2007) Characterization of developing microbial communities in Mount St. Helens pyroclastic substrate. Soil Biol Biochem 39:2496-2507. doi:10.1016/j.soilbio.2007.05.010

[10] Herrera A, Cockell CS, Self S, Blaxter M, Reitner J, Arp G, Dröse W, Thorsteinsson T, Tindle AG (2008) Bacterial colonization and weathering of terrestrial obsidian in Iceland. Geomicrobiol J, 25:25-47. doi:10.1080/01490450701828982

[11] Gomez-Alvarez V, King GM, Nüsslein K (2007) Comparative bacterial diversity in recent Hawaiian volcanic deposits of different ages. FEMS Microbiol Ecol 60:60-73. doi:10.1111/j.1574-6941.2006.00253.x

[12] Kelly L, Cockell C, Piceno Y, Andersen G, Thorsteinsson T, Marteinsson V (2010) Bacterial diversity of weathered terrestrial icelandic volcanic glasses. Microb Ecol 60:740-752. doi:10.1007/s00248-010-9684-8

[13] Schwabe GH (1970) On the algal settlement in craters on Surtsey during summer 1968. Surtsey Research Progress Report, V:68-69.

[14] Kristinsson H (1970) Report on the lichenological work on Surtsey and in Iceland. Surtsey Research Progress Report V:52.

[15] Kristinsson H (1974) Lichen colonization in Surtsey 1971-1973. Surtsey Research Progress Report VII:9-16.

[16] Schwabe GH, Behre K (1972) Algae on Surtsey in 1969-1970. Surtsey Research Progress Report VI:85-89.

[17] Brock TD (1973) Primary colonization of Surtsey, with special reference to the bluegreen algae. Oikos 24:239-243.

[18] Englund B. (1976) Nitrogen fixation by free-living microorganisms on the lava field of Heimaey, Iceland. Oikos 27:428-432. doi:10.2307/3543461 
[19] King GM (2003) Contributions of atmospheric CO and hydrogen uptake to microbial dynamics on recent Hawaiian volcanic deposits. Appl Environ Microb 69:4067-4075. doi:10.1128/AEM.69.7.4067-4075.2003

[20] Weber CF, King GM (2010) Distribution and diversity of carbon monoxide-oxidizing bacteria and bulk bacterial communities across a succession gradient on a Hawaiian volcanic deposit. Environ Microbiol 12:1855-1867. doi: 10.1111/j.14622920.2010.02190.x

[21] Kelly LC, Cockell CS, Herrera-Belaroussi A, Piceno YM, Andersen G, DeSantis TZ, Brodie E, Thorsteinsson T, Marteinsson V, Poly F, LeRoux X. (2011) Bacterial diversity of terrestrial crystalline volcanic rocks, Iceland. Microb Ecol 62:69-79. doi: $10.1007 / \mathrm{s} 00248-011-9864-1$

[22] Cockell CS, Olsson-Francis K, Herrera A, Kelly L, Thorsteinsson T, Marteinsson V (2009) Bacteria in weathered basaltic glass, Iceland. Geomicrobiol J 26:491-507. doi:10.1080/01490450903061101

[23] Sigmundsson F, Hreinsdóttir S, Hooper A, Árnadóttir T, Pedersen R, Roberts M, Óskarsson N, Auriac A, Decriem J, Einarsson P, Hensch M, Ófeigsson BG, Sturkell E, Sveinbjörnsson H and Feigl KL (2010) Intrusion triggering of the 2010 Eyjafjallajokull explosive eruption. Nature 468:426-430. doi:10.1038/nature09558

[24] Edwards BR, Gudmundsson MT, Thordarson T, Magnússon E, Höskuldsson A, Oddsson B, Haklar JP (2012) Interactions between lava and snow/ice during the 2010 Fimmvörðuháls eruption, south-central Iceland. J Geophy Res 117:B04302. doi:10.1029/2011JB008985

[25] Ramsey MH, Potts PJ, Webb PC, Watkins P, Watson JS, Coles BJ (1995) An objective assessment of analytical method precision: Comparison of ICP-AES and XRF for the analysis of silicate rocks. Chem Geol 124:1-19. doi:10.1016/0009-2541(95)00020-M 
[26] Watson JS (1996) Fast, simple method of powder pellet preparation for x-ray fluorescence analysis. X-Ray Spectrom 25:173-174.

[27] Rippka R, Deruelles J, Waterbury JB, Herdman M, Stanier RY (1979) Generic assignments, strain histories and properties of pure cultures of cyanobacteria. J Gen Microbiol 111:1-61.

[28] Sattley WM, Madigan MT (2006) Isolation, characterization, and ecology of cold-active, chemolithotrophic, sulfur-oxidizing bacteria from perennially ice-covered Lake Fryxell, Antarctica. Appl Environ Microb 72:5562-5568. doi:10.1128/AEM.00702-06

[29] Atlas RM (2004) Handbook of microbiological media. CRC Press, Florida, USA.

[30] Edwards U, Rogall T, Blöcker, Emde M, Böttger E (1989) Isolation and direct complete nucleotide determination of entire genes. Characterization of a gene coding for $16 \mathrm{~S}$ ribosomal RNA. Nuc Acids Res 17:7843-7853. doi:10.1093/nar/17.19.7843

[31] Bruce KD, Hiorns WD, Hobman JL, Osborn AM, Strike P, Ritchie DA (1992) Amplification of DNA from native populations of soil bacteria by using the polymerase chain reaction. Appl Environ Microb 58:3413-3416.

[32] Calvaruso C, Turpault MP, Leclerc E, Ranger J, Garbaye J, Uroz S, Frey-Klett P (2010) Influence of forest trees on the distribution of mineral weathering-associated bacterial communities of the Scleroderma citrinum mycorrhizosphere. Appl Environ Microb 76:4780-4787. doi: 10.1128/AEM.03040-09

[33] Nübel U, Garcia-Pichel F, Muyzer G. (1997) PCR primers to amplify 16S rRNA genes from cyanobacteria. Appl Environ Microb 63:3327-3332.

[34] Borneman J, Hartin RJ (2000) PCR primers that amplify fungal rRNA genes from environmental samplesf. Appl Environ Microb 66:4356-4360. doi: 10.1128/AEM.66.10.4356-4360.2000 
[35] Schwieger F, Tebbe C (1998) A new approach to utilize PCR-single-strand-conformation polymorphis for 16S rRNA gene-based microbial community analysis. Appl Environ Microb 64: 4870-4876.

[36] Herrera A, Cockell CS (2007) Exploring microbial diversity in volcanic environments: A review of methods in DNA extraction. J Microbiol Meth 70:1-12. doi:10.1016/j.mimet.2007.04.005

[37] DeSantis TZ, Hugenholtz P, Larsen N, Rojas M, Brodie EL, Keller K, Huber T, Dalevi D, Hu P, Andersen GL (2006) Greengenes, a chimera-checked 16S rRNA gene database and workbench compatible with arb. Appl Environ Microb 72:5069-5072. doi:10.1128/AEM.03006-05

[38] Schloss PD, Westcott SL, Ryabin T, Hall JR, Hartmann M, Hollister EB, et al. (2009) Introducing MOTHUR: Open-source, platform-independent, community-supported software for describing and comparing microbial communities. Appl Environ Microb 75:7537-7541. doi:10.1128/AEM.01541-09

[39] Felsenstein J (1993) Phylip (phylogeny inference package) version 3.68.

[40] Singleton DR, Furlong MA, Rathbun SL and Whitman WB (2001) Quantitative comparisons of $16 \mathrm{~S}$ rRNA gene sequence libraries from environmental samples. Appl Environ Microb 67:4374-4376. doi:10.1128/AEM.67.9.4374-4376.2001

[41] Wang Q, Garrity GM, Tiedje JM, Cole JR (2007) Naive Bayesian classifier for rapid assignment of rRNA sequences into the new bacterial taxonomy. Appl Environ Microb 73:5261-5267. doi:10.1128/AEM.00062-07

[42] Tamura KD, Dudley J, Nei M, Kumar S (2007) Mega4: Molecular evolutionary genetics analysis (mega) software version 4.0. Mol Biol Evol 24:1596-1599. doi:10.1093/molbev/msm092 
[43] Le Bas MJ, Le Maitre RW, Streckeisen A, Zanettin B (1986) A chemical classification of volcanic rocks based on the total alkali-silica diagram. J Petrol 27:745-750.

[44] Chao A (1984) Non-parametric estimation of the number of classes in a population. Scand J Stat 11:783 - 791.

[45] Kaštovská K, Elster J, Stibal M, Šantrůčková H (2005) Microbial assemblages in soil microbial succession after glacial retreat in Svalbard (High Arctic). Microb Ecol 50:396-407. doi:10.1007/s00248-005-0246-4

[46] Nemergut D, Anderson S, Cleveland C, Martin A, Miller A, Seimon A, Schmidt SK (2007) Microbial community succession in an unvegetated, recently deglaciated soil. Microb Ecol 53:110-122. doi:10.1007/s00248-006-9144-7

[47] Henriksson LE, Henriksson E (1982) Concerning the biological nitrogen fixation on Surtsey. Surtsey Research Progress Report, IX, 9-12.

[48] Chapin FS, Walker LR, Fastie CL, Sharman LC (1994) Mechanisms of primary succession following deglaciation at Glacier Bay, Alaska. Ecol Monogr 64:149-175. doi:10.2307/2937039

[49] Duc L, Noll M, Meier B, Bürgmann H, Zeyer J (2009) High diversity of diazotrophs in the forefield of a receding alpine glacier. Microb Ecol 57:179-190. doi:10.1007/s00248-008-9408-5

[50] King GM (2007) Chemolithotrophic bacteria: distributions, functions and significance in volcanic environments. Microbes Environ 22:309-319. doi:10.1264/jsme2.22.309

[51] Walker LR, del Moral R (2003) Primary Succession and Ecosystem Rehabilitation. Cambridge University Press, Cambridge, UK.

[52] Vaitilingom M Deguillaume L, Vinatier V, Sancelme M, Amato P, Chaumerliac N, Delort AM (2013) Potential impact of microbial activity on the oxidant capacity and 
organic carbon budget in clouds. Proc Natl Acad Sci USA 110: 559-564. doi: 10.1073/pnas. 1205743110

[53] Lu H, Fujimura R, Sato Y, Nanba K, Kamijo T, Ohta H (2008) Characterization of Herbaspirillum- and Limnobacter-related strains isolated from young volcanic deposits in Miyake-Jima island, Japan. Microbes Environ 23:66-72. doi:10.1264/jsme2.23.6

[54] Heue KP, Brenninkmeijer CAM, Baker AK, Rauthe-Schöch A, Walter D, Wagner T, Hörmann C, Sihler H, Dix B, Frieß U, Platt U, Martinsson BG, van Velthoven PFJ, Zahn A, Ebinghaus R (2011) $\mathrm{SO}_{2}$ and $\mathrm{BrO}$ observation in the plume of Eyjafjallajökull volcano 2010: CARIBIC and GOME-2 retrievals. Atmos Chem Phys 11:2973-2989. doi:10.5194/acp-11-2973-2011

[55] Schütte UME, Abdo Z, Foster J, Ravel J, Bunge J, Solheim B, Forney LJ (2010) Bacterial diversity in a glacier foreland of the high Arctic. Mol Ecol 19:54-66. doi:10.1111/j.1365-294X.2009.04479.x 
Table 1. Fimmvörðuháls isolates and their closest cultured relatives currently deposited in GenBank, as determined by partial 16S rRNA gene sequence comparison. In instances where the closest cultured organism or organisms are unclassified, the nearest classified cultured organism is also shown. Where multiple Fimmvörðuháls isolates returned the same hit (usually representing isolates within the same OTU; see text), the accession number of only one Fimmvörðuháls isolate is given. For ease of reporting, data for Arthrobacter, Pseudomonas and Sphingomonas, species isolated in abundance, are condensed. Accessions in bold font indicate those isolates which are cluster within within the most abundant clone library OTUs, as determined during Mothur analysis (see text and Table 2).

\begin{tabular}{|c|c|c|c|c|c|c|}
\hline $\begin{array}{l}\text { solate (this } \\
\text { study) } \\
\text { Photoautotrophs } \\
\end{array}$ & $\begin{array}{l}\text { GenBank } \\
\text { Accession }\end{array}$ & $\begin{array}{l}\text { \% } \\
\text { Match }\end{array}$ & Phylum & $\begin{array}{l}\text { Nearest Cultured Organism } \\
\text { (GenBank) }\end{array}$ & Environment & Reference \\
\hline JF418020 (B) & FJ002185 & 97 & Bacillariophyta & Pennate diatom sp, CCAP 1008/1 & & unpublished study \\
\hline JF418123 (B) & D11348 & 92 & Chlorophyta & Chlorella saccharophilia & & Oyzizu et al. 1992 \\
\hline JF418116 ${ }^{(B)}$ & EU912438 & 94 & Chlorophyta & Vaucheria litorea chloroplast & & Rumpho et al. 2008 \\
\hline JF418019 (B) & AM709632 & 98 & Cyanobacteria & Pseudanabaena sp. PCC 6903 & & Marin et al. 2007 \\
\hline $\begin{array}{l}\text { JF418021 } \\
\text { Bacteria }\end{array}$ & GU935361 & 98 & Cyanobacteria & Pseudanabaenoideae sp. & drinking water reservoir sediment & unpublished study \\
\hline$\overline{J F 418135^{(S)}}$ & GQ477173 & 99 & Actinobacteria & Arthrobacter sp. RKS6-6 & Himalayan glacial soil & unpublished study \\
\hline JF418068 ${ }^{\text {(NA) }}$ & JQ977602 & 99 & Actinobacteria & Arthrobacter sp. Alb6 & root, Tianshan Mts, China & unpublished study \\
\hline JF418119 & KC236857 & 99 & Actinobacteria & Arthrobacter sp. B2108 & paddy soil & unpublished study \\
\hline JF418087 ${ }^{\text {(NA) }}$ & JX949837 & 99 & Actinobacteria & Arthrobacter sp. TMT1-38 & Chinese glacier & unpublished study \\
\hline JF418081 (NA) & JQ977457 & 99 & Actinobacteria & Arthrobacter sp. Zs11 & rhizosphere soil, Tianshan Mts, China & unpublished study \\
\hline JF418036 ${ }^{(\mathrm{N})}$ & JX876867 & 99 & Actinobacteria & Frondihabitans sp. GRS42 & maple syrup & unpublished study \\
\hline JF418063 ${ }^{\text {(NA) }}$ & HQ728400 & 97 & Unclassified & Bacterium M25 & Arabidopsis thaliana phyllosphere & unpublished study \\
\hline & EF540450 & 97 & Actinobacteria & Leifsonia sp. & Semi-coke & unpublished study \\
\hline JF418118 (B) & KC618504 & 100 & Actinobacteria & Rhodococcus erythropolis & rhizosphere soil & unpublished study \\
\hline JF418034 ${ }^{(\mathrm{N})}$ & HQ113383 & 99 & Alphaproteobacteria & Caulobacter sp. BSL1 & Daphnia magna digestive tract & $\begin{array}{l}\text { Martin-Creuzburg, Beck \& } \\
\text { Freese } 2011\end{array}$ \\
\hline JF418035 ${ }^{(\mathrm{N})}$ & AB531422 & 100 & Alphaproteobacteria & Mesorhizobium sp. IV-10 & grassland soil & Kasahara and Hattori, 1991 \\
\hline JF418133 (S, N) & DQ490353 & 99 & Alphaproteobacteria & Methylobacteriaceae bacterium & volcanic deposit Kilauea volcano & unpublished study \\
\hline JF418045 (N, NA) & JQ977299 & 100 & Alphaproteobacteria & Rhizobium sp. Axs14 & rhizosphere soil, Tianshan Mts., China & unpublished study \\
\hline JF417995 (NA) & JQ396566 & 99 & Alphaproteobacteria & Rhizobium sp. MN6-12 & Arctic rhizosphere & unpublished study \\
\hline
\end{tabular}




\begin{tabular}{|c|c|c|c|c|c|c|}
\hline $\begin{array}{l}\text { solate (this } \\
\text { study) }\end{array}$ & $\begin{array}{l}\text { GenBank } \\
\text { Accession }\end{array}$ & $\begin{array}{l}\% \\
\text { Match }\end{array}$ & Phylum & $\begin{array}{l}\text { Nearest Cultured Organism } \\
\text { (GenBank) }\end{array}$ & Environment & Reference \\
\hline JF418114 & NR029327 & 97 & Alphaproteobacteria & Sphingomonas asaccharolytica $\mathrm{Y}-345$ & type strain & unpublished study \\
\hline JF418101 (NA) & HQ825039 & 99 & Alphaproteobacteria & Sphingomonas sp. & cryoconite hole, Austria & Lee et al.2011 \\
\hline JF418097 (N, NA) & Z23157 & 100 & Alphaproteobacteria & Sphingomonas sp. BF14 & air-handling system & Hugenholtz et al. 1995 \\
\hline JF418111 (NA) & JX949544 & 97 & Bacteroidetes & Mucilaginibacter sp. MDB2-30 & Chinese glacier & unpublished study \\
\hline JF418079 (NA) & EF550172 & 99 & Betaproteobacteria & Acidovorax sp. & arsenic contaminated soil, China & Fan et al. 2008 \\
\hline \multirow[t]{2}{*}{$\mathrm{JF} 418028^{(\mathrm{N})}$} & GU213404 & 99 & Betaproteobacteria & Beta proteobacterium 224 & fresh granite, Damma Glacier & unpublished study \\
\hline & JX304660 & 99 & Betaproteobacteria & Herbaspirillum sp. JJ2206 & Korean soil & unpublished study \\
\hline \multirow[t]{2}{*}{ JF418093 ${ }^{(\mathrm{N}, \mathrm{NA})}$} & FR682708 & 99 & Betaproteobacteria & Beta proteobacterium R-36369 & soil, Dronning Maud Land, Antarctica & Peeters, Ertz \& Willems 2011 \\
\hline & JX304660 & 99 & Betaproteobacteria & Herbaspirillum sp. JJ2206 & Korean soil & unpublished study \\
\hline JF418105 (NA) & AY561571 & 98 & Betaproteobacteria & Beta proteobacterium RG-4 & vadose zone sediment & Fredrickson et al. 2004 \\
\hline JF418103 ${ }^{\text {(NA) }}$ & GQ354570 & 98 & Betaproteobacteria & Duganella sp. HMD2171 & mesotrophic artificial lake & unpublished study \\
\hline JF418100 (NA) & AB495152 & 99 & Betaproteobacteria & Duganella zoogloeoides & & Tani et al. 2011 \\
\hline JF418127 & EU130968 & 99 & Betaproteobacteria & Hydrogenophaga sp. & water treatment filter & $\begin{array}{l}\text { Magic-Knezev, Wullings \& } \\
\text { Van der Kooij } 2009\end{array}$ \\
\hline JF418038 & D84572 & 99 & Betaproteobacteria & Janthinobacterium sp. S21104 & & Mitsui et al. 1997 \\
\hline JF418117 ${ }^{(\mathrm{B})}$ & JX177700 & 99 & Betaproteobacteria & Limnobacter sp. 2D3 & Baltic sea surface water & unpublished study \\
\hline JF706699 (NA, B) & NR044274 & 98 & Betaproteobacteria & Massilia brevitalea & type strain & Zul, Wanner \& Overmann 2008 \\
\hline JF418121 (B) & GQ200828 & 99 & Betaproteobacteria & Massilia sp. M1 & raw milk & unpublished study \\
\hline JF418065 (NA) & JX950006 & 99 & Betaproteobacteria & Massilia sp. TMT2-56-2 & Chinese glacier & unpublished study \\
\hline JF418044 ${ }^{(\mathrm{N})}$ & HM224491 & 99 & Betaproteobacteria & Massilia sp. TPD44 & permafrost headwaters, Urumqi River & unpublished study \\
\hline JF418122 (B) & AB769202 & 99 & Betaproteobacteria & Methylibium sp. UTPF84a & rice paddy field soil & unpublished study \\
\hline JF418089 ${ }^{(\mathrm{NA})}$ & FR682711 & 99 & Betaproteobacteria & Polaromonas sp. & soil, Dronning Maud Land, Antarctica & Peeters, Ertz \& Willems 2011 \\
\hline JF418129 ${ }^{(S)}$ & AJ316618 & 96 & Betaproteobacteria & Thiobacillus plumbophilus DSM6690 & & \\
\hline JF418113 ${ }^{(\mathrm{NA})}$ & JQ977458 & 99 & Betaproteobacteria & Variovorax sp. Zs13 & rhizosphere soil, Tianshan Mts, China & unpublished study \\
\hline JF418026 ${ }^{(\mathrm{N})}$ & СР000359 & 97 & Deinococcus- & Deinococcus geothermalis DSM11300 & & unpublished study \\
\hline JF418012 (NA) & EF093134 & 99 & Deinococcus- & Deinococcus sp. VTT & Scottish stone monument & Suihko et al. 2007 \\
\hline \multirow[t]{3}{*}{ JF418144 (S, B) } & HE613268 & 92 & Firmicutes & Alicyclobacillus sp. & human blood & unpublished study \\
\hline & DQ999995 & 93 & Firmicutes & Bacillales bacterium & opalinus clay & unpublished study \\
\hline & AJ607430 & 92 & Firmicutes & Alicyclobacillus pohliae & geothermal soil, Antarctica & Imperio, Viti \& Marri 2008 \\
\hline JF418088 (NA) & KC865283 & 99 & Firmicutes & Staphylococcus warneri 11BP & & Serradilla et al. in press \\
\hline & FM955889 & 100 & Gammaproteobacteri & & mat Midre I ovenhreen & unpublished study \\
\hline $\begin{array}{l}\text { JF418010 (S, NA) } \\
\text { Fungi }\end{array}$ & JQ977479 & 100 & Gammaproteobacteri & Pseudomonas sp. Bma1 & rhizoplane, Tianshan Mts,, China & unpublished study \\
\hline & & 99 & & & & \\
\hline JF418153 (NA) & EU940042 & 100 & Ascomycota & Mniaecia nivea M167 & A bryosymbiont. & Stenroos et al. 2010 \\
\hline JF418150 (NA) & JX470336 & 100 & Ascomycota & Cladosporium cladosporioides & Moon-1 Rover internal surface & unpublished study \\
\hline JF418147 ${ }^{(\mathrm{NA})}$ & JX303663 & 99 & Ascomycota & Aureobasidium pullulans ZH1 & Athletes foot-infected skin & unpublished study \\
\hline JF418152 (NA) & AF548077 & 99 & Ascomycota & Microdochium nivale UPSC 3273 & & Wu et al. 2003 \\
\hline
\end{tabular}


Table 2. The most abundant OTUs (defined at 97\% sequence similarity) among Fimmvörðuháls clone libraries. The two most abundant OTUs from each library, nine in total among all libraries due to abundance of certain OTUs in multiple libraries, are shown, and an accession number for a clone representative of that OTU. Number in parenthesis after OTU designation refers to alternative OTU designation in the combined clone library and isolate dataset (see text and Fig. 4; boxed branches). Cumultative contributions of each OTU to all libraries, their average and range of contribution, in addition to their nearest cultured and uncultured GenBank matches are also shown. Information regarding the known nutritional abilities of the associated cultured genera are also provided, and are discussed in the text. 


\begin{tabular}{|c|c|c|c|c|c|c|c|c|c|c|c|}
\hline \multirow{2}{*}{$\begin{array}{l}\text { OTU and } \\
\text { accession }\end{array}$} & \multirow{2}{*}{$\begin{array}{l}\% \text { in } \\
\text { libraries } \\
\text { (of total) }\end{array}$} & \multirow{2}{*}{$\begin{array}{l}\text { Average } \\
\text { \% per } \\
\text { library } \\
\text { (range) }\end{array}$} & \multirow[t]{2}{*}{ Isolates } & \multicolumn{3}{|c|}{ GenBank - closest uncultured } & \multicolumn{5}{|c|}{ Genbank - closest cultured organism } \\
\hline & & & & Accession & $\begin{array}{l}\% \\
\text { id }\end{array}$ & Source & Accession & $\%$ id & $\begin{array}{l}\text { Genus/ } \\
\text { species }\end{array}$ & $\begin{array}{l}\text { Source (where } \\
\text { disclosed) }\end{array}$ & $\begin{array}{l}\text { Nutrition associated } \\
\text { with genus }\end{array}$ \\
\hline $\begin{array}{l}\text { OTU63 (73) } \\
\text { HQ899770 }\end{array}$ & 29.7 & $\begin{array}{l}29.8 \\
(9.4-48.0)\end{array}$ & Yes & $\begin{array}{l}\text { JQ684286 } \\
\text { FM872918 }\end{array}$ & $\begin{array}{l}99 \\
99\end{array}$ & $\begin{array}{l}\text { Permafrost soil } \\
\text { Floor dust }\end{array}$ & $\begin{array}{l}\text { FR682708 } \\
\text { JX304660 }\end{array}$ & 99 & $\begin{array}{l}\text { Beta proteobacterium } \\
\text { R-36369 } \\
\text { Herbaspirillum } \mathrm{sp.}\end{array}$ & Antarctic soil & Diazotrophic \\
\hline $\begin{array}{l}\text { OTU45 (44) } \\
\text { HQ899746 }\end{array}$ & 10.0 & $\begin{array}{l}10.4 \\
(0.0-36.3)\end{array}$ & No & KC620647 & 98 & $\begin{array}{l}\text { Acid mine drainage } \\
\text { sample }\end{array}$ & AJ316618 & 96 & $\begin{array}{l}\text { Thiobacillus } \\
\text { plumbophilus } \\
\text { DSM6690 }\end{array}$ & & $\begin{array}{l}\text { Galena, H2 and iron } \\
\text { oxidizer }\end{array}$ \\
\hline $\begin{array}{l}\text { OTU54 (71) } \\
\text { HQ899721 }\end{array}$ & 9.8 & $\begin{array}{l}9.7 \\
(1.0-25.5)\end{array}$ & Yes & JN178902 & 99 & $\begin{array}{l}\text { Kartchner Caverns, } \\
\text { USA }\end{array}$ & NR074725 & 99 & $\begin{array}{l}\text { Polaromonas sp. } \\
\text { JS666 }\end{array}$ & & Nitrogen fixation \\
\hline $\begin{array}{l}\text { OTU38 (37) } \\
\text { HQ899891 }\end{array}$ & 9.0 & $\begin{array}{l}9.0 \\
(0.0-29.9)\end{array}$ & No & DQ228366 & 99 & Bench glacier & AB080643 & 97 & Sulfuricurvum kujiense & $\begin{array}{l}\text { Underground } \\
\text { crude oil } \\
\text { storage cavity }\end{array}$ & $\begin{array}{l}\text { Sulfur-oxidizing } \\
\text { chemolithotroph }\end{array}$ \\
\hline $\begin{array}{l}\text { OTU60 (76) } \\
\text { HQ898929 }\end{array}$ & 7.5 & $\begin{array}{l}7.5 \\
(0.0-17.2)\end{array}$ & Yes & JF703392 & 99 & $\begin{array}{l}\text { Root and rhizosphere } \\
\text { soil }\end{array}$ & D84572 & 99 & $\begin{array}{l}\text { Janthinobacterium sp. } \\
\text { S21104 }\end{array}$ & & \\
\hline $\begin{array}{l}\text { OTU59 (53) } \\
\text { HQ899732 }\end{array}$ & 6.3 & $\begin{array}{l}6.3 \\
(0.0-23.4)\end{array}$ & No & $\begin{array}{l}\text { JF189275 } \\
\text { KC286734 }\end{array}$ & $\begin{array}{l}99 \\
98\end{array}$ & $\begin{array}{l}\text { Human skin } \\
\text { Glacial snow }\end{array}$ & $\begin{array}{l}\text { EU636046 } \\
\text { HQ699437 } \\
\text { FJ812350 }\end{array}$ & $\begin{array}{l}97 \\
97 \\
96\end{array}$ & $\begin{array}{l}\text { Antarctic bacterium } \\
\text { GA0L } \\
\text { Actimicrobium } \\
\text { antarcticum } \\
\text { Herbaspirillum sp. }\end{array}$ & $\begin{array}{l}\text { Collins glacier } \\
\text { Seashore water, } \\
\text { Antarctica } \\
\text { Soil }\end{array}$ & Diazotrophic \\
\hline $\begin{array}{l}\text { OTU49 (87) } \\
\text { HQ899197 }\end{array}$ & 3.9 & $\begin{array}{l}3.7 \\
(0.0-28.4)\end{array}$ & Yes & KC620646 & 98 & $\begin{array}{l}\text { Acid mine drainage } \\
\text { sample }\end{array}$ & AJ316618 & 96 & $\begin{array}{l}\text { Thiobacillus } \\
\text { plumbophilus } \\
\text { DSM6690 }\end{array}$ & & $\begin{array}{l}\text { Galena, H2 and iron } \\
\text { oxidizer }\end{array}$ \\
\hline $\begin{array}{l}\text { OTU62 (55) } \\
\text { HQ900023 }\end{array}$ & 2.2 & $\begin{array}{l}2.2 \\
(0.0-12.8)\end{array}$ & No & AB488378 & 95 & Rice paddy soil & $\begin{array}{l}\text { HE613268 } \\
\text { AB362268 }\end{array}$ & $\begin{array}{l}95 \\
94\end{array}$ & $\begin{array}{l}\text { Alicyclobacillus sp. } \\
\text { Alicyclobacillus sp. }\end{array}$ & $\begin{array}{l}\text { Human blood } \\
\text { Subseafloor } \\
\text { sediment }\end{array}$ & \\
\hline $\begin{array}{l}\text { OTU47 (45) } \\
\text { HQ899794 }\end{array}$ & 2.0 & $\begin{array}{l}1.9 \\
(0.0-10.4)\end{array}$ & No & KC110974 & 97 & Soil microcosm & NR_074693 & 98 & $\begin{array}{l}\text { Methylotenera } \\
\text { versatilis }\end{array}$ & & Methylotroph \\
\hline
\end{tabular}


Fig. 1. Location map. Hillshade map generated from LiDAR data collected on NERC Airborne Research and Survey Facility Flight UR10/02 on 16 September 2010 and filtered with Sun's denoising algorithm (Stevenson et al., 2010). The sampling sites, denoted by numbers 1,5 and 9 , are located on the Fimmvörðuháls lava flow, between the Eyjafjallajökull and Mýrdalsjökull glaciers, in Southern Iceland. Flows (delineated by a broken line), originated from two craters, their positions as indicated by triangles (inset map; box denotes area of main map).

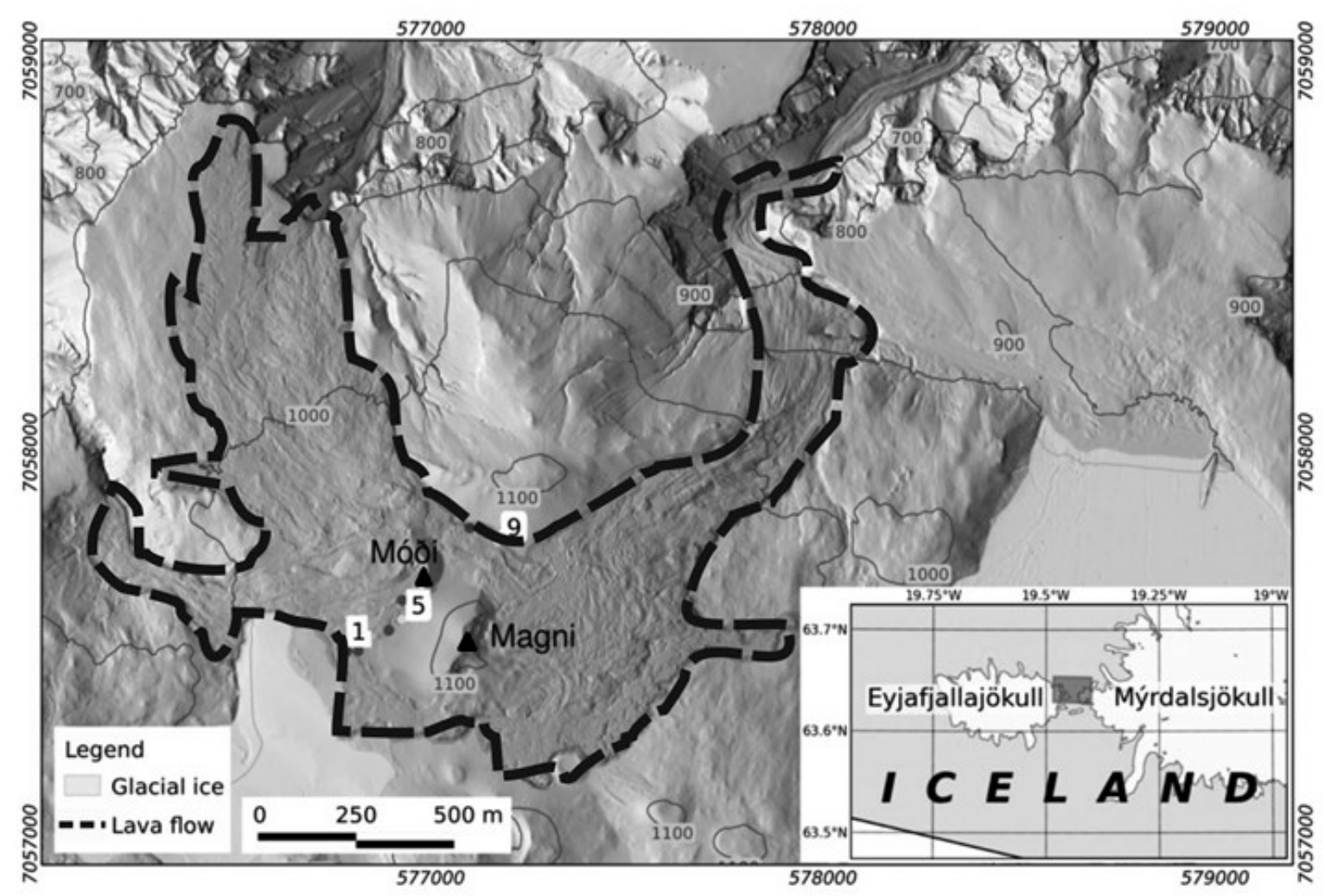


Fig. 2. Abundances of cells detected by fluorescent microscopy in lava samples (cells/g dry weight). Abundances correspond to the average for the three replicates for each site and season. Error bars represent standard deviations.

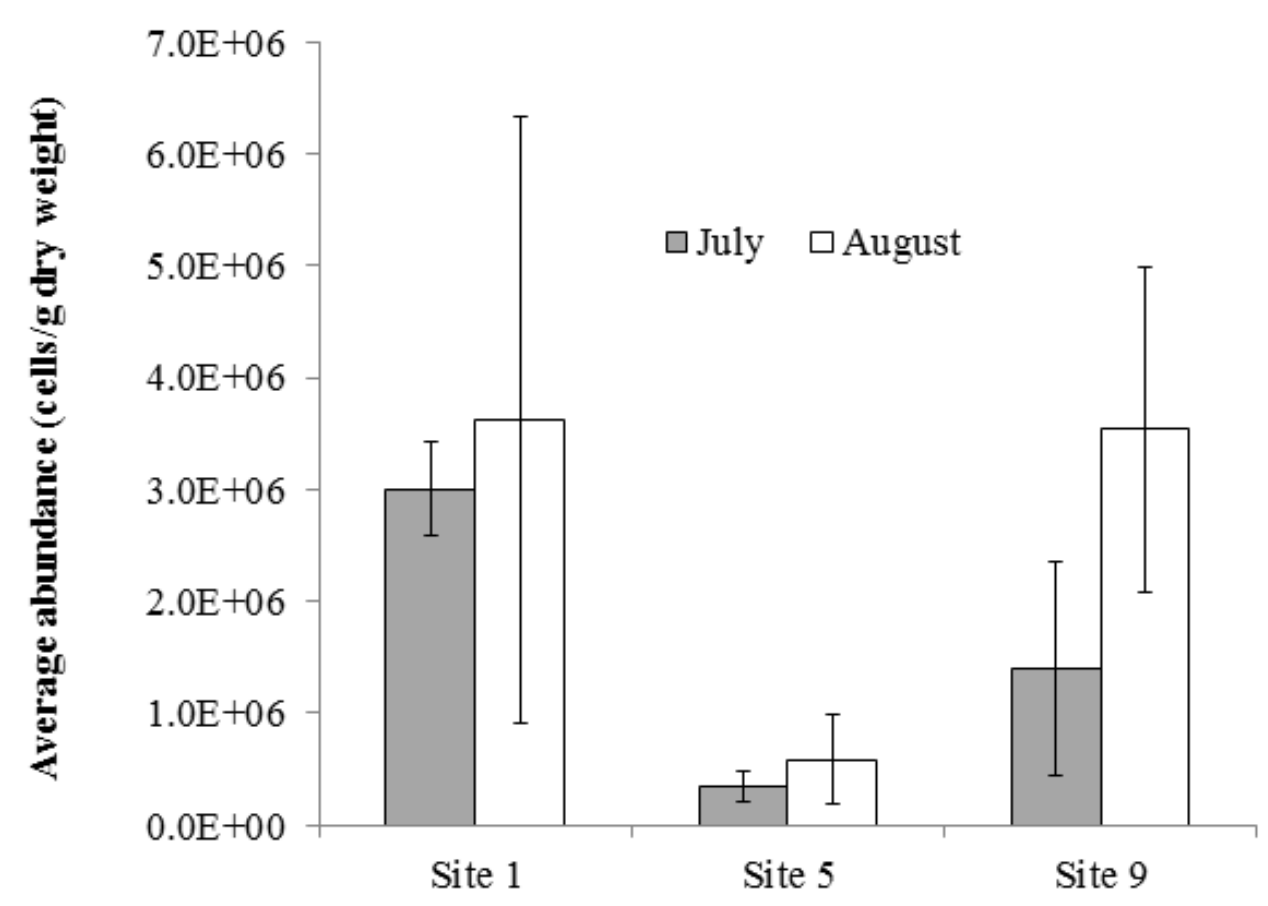


Fig 3. Richness and diversity of 16S rRNA gene clone libraries. Chao1 richness, and Shannon and Simpson diversity indices of individual Fimmvörðuháls lava samples, calculated in MOTHUR using 16S rRNA gene clone library sequences at 97\% sequence identity. Upper and lower confidence intervals are also shown.

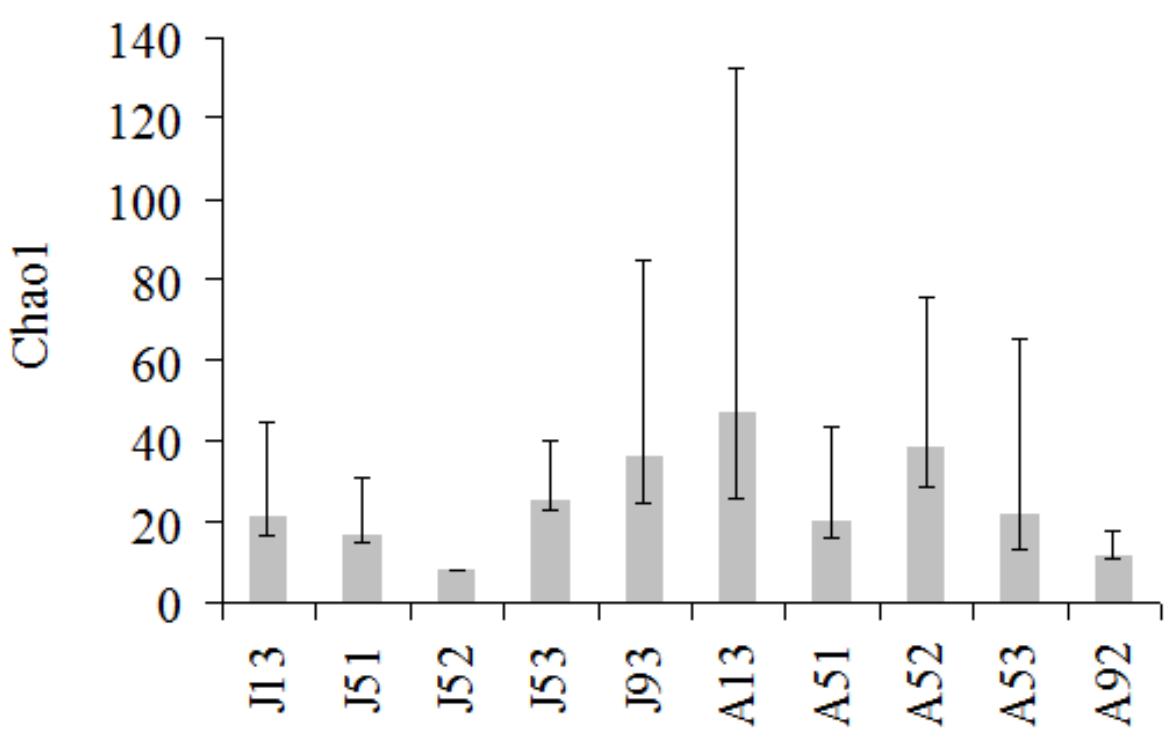

Sample

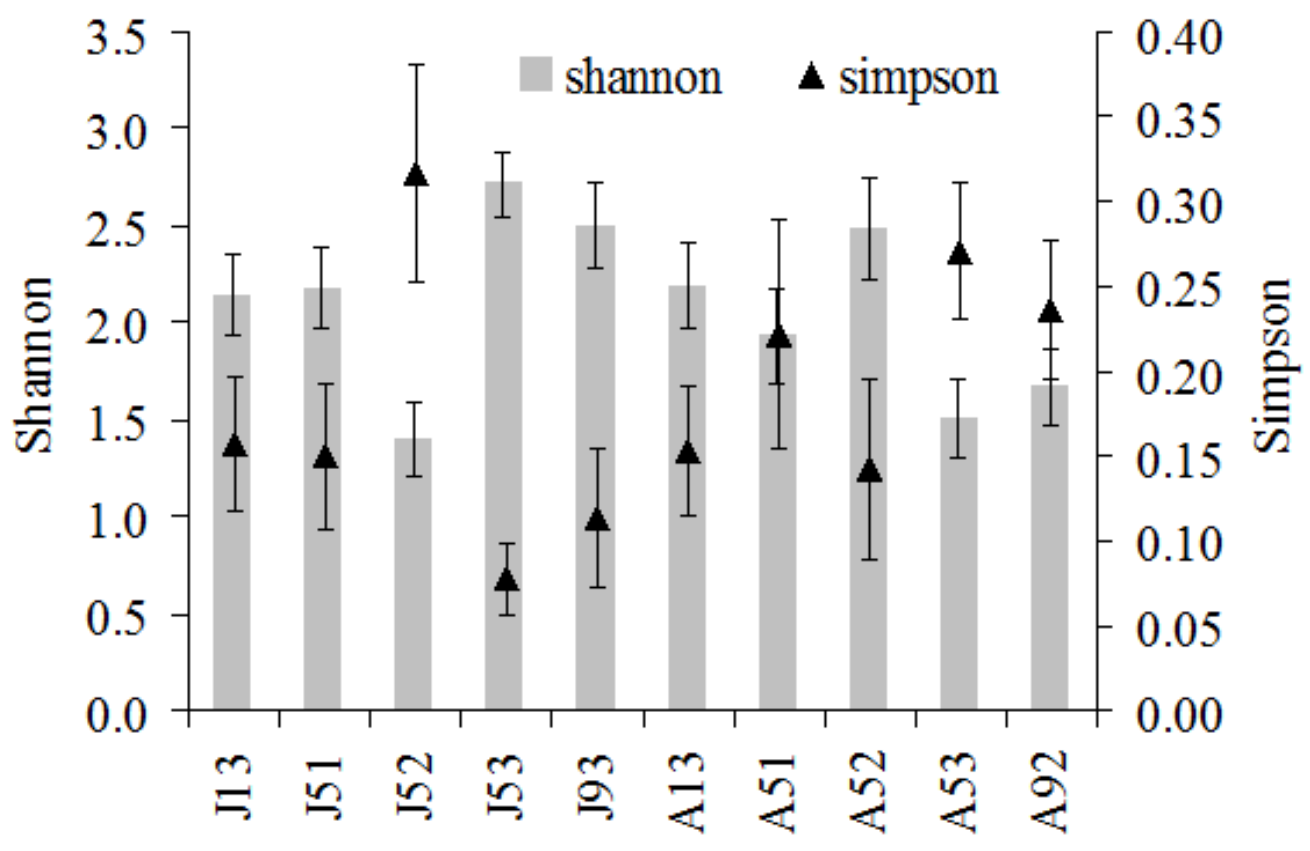

Sample 
Fig. 4. Classification of $16 \mathrm{~S}$ rRNA gene clones. Phylum- (and Proteobacteria sub-phylum) level classifications of bacterial 16S rRNA gene clones from July and August lava libraries. 'Weathered' represents basalt lava from the Icelandic Hnausahraun lava flow, erupted circa 150-300 A.D. (Kelly et al. 2011) and is given for comparison. All samples were analysed in the same manner. 'Others' refers to other phyla, each represented by a maximum of two clones in any Fimmvörðuháls library.

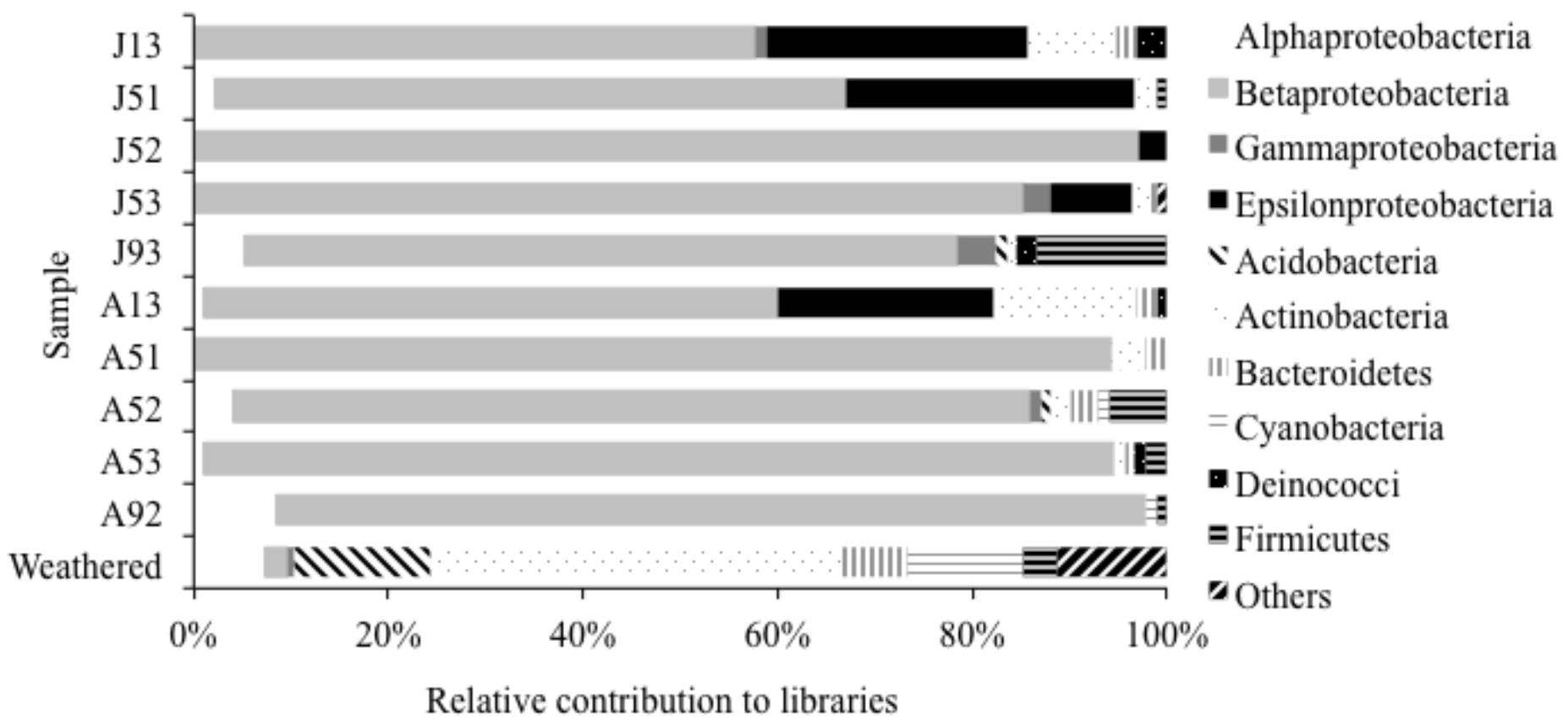


Fig. 5. Neighbor-Joining (NJ) phylogenetic tree, based on an alignment of 16S rRNA gene clones and isolate sequences from the Fimmvörðuháls lava flow. Numbers following OTU designations indicate the number of sequences represented by the OTU. a) full tree; b) expansion of Betaproteobacteria cluster of full tree. * indicates the OTU is represented by isolates only (number given in parentheses). ** Indicates the OTU is represented by both isolates and clones (numbers, respectively given in parentheses). The remaining OTUs are represented solely by clones (number given in parentheses). Highlighted OTUs represent those most abundant in libraries (Table 2). Values at nodes represent bootstrap values for the Maximum Likelihood (in parentheses) or Neighbour-Joining tree respectively, and are shown only where values exceeded $60 \%$ in one or both trees. 
Figure 5 (a)

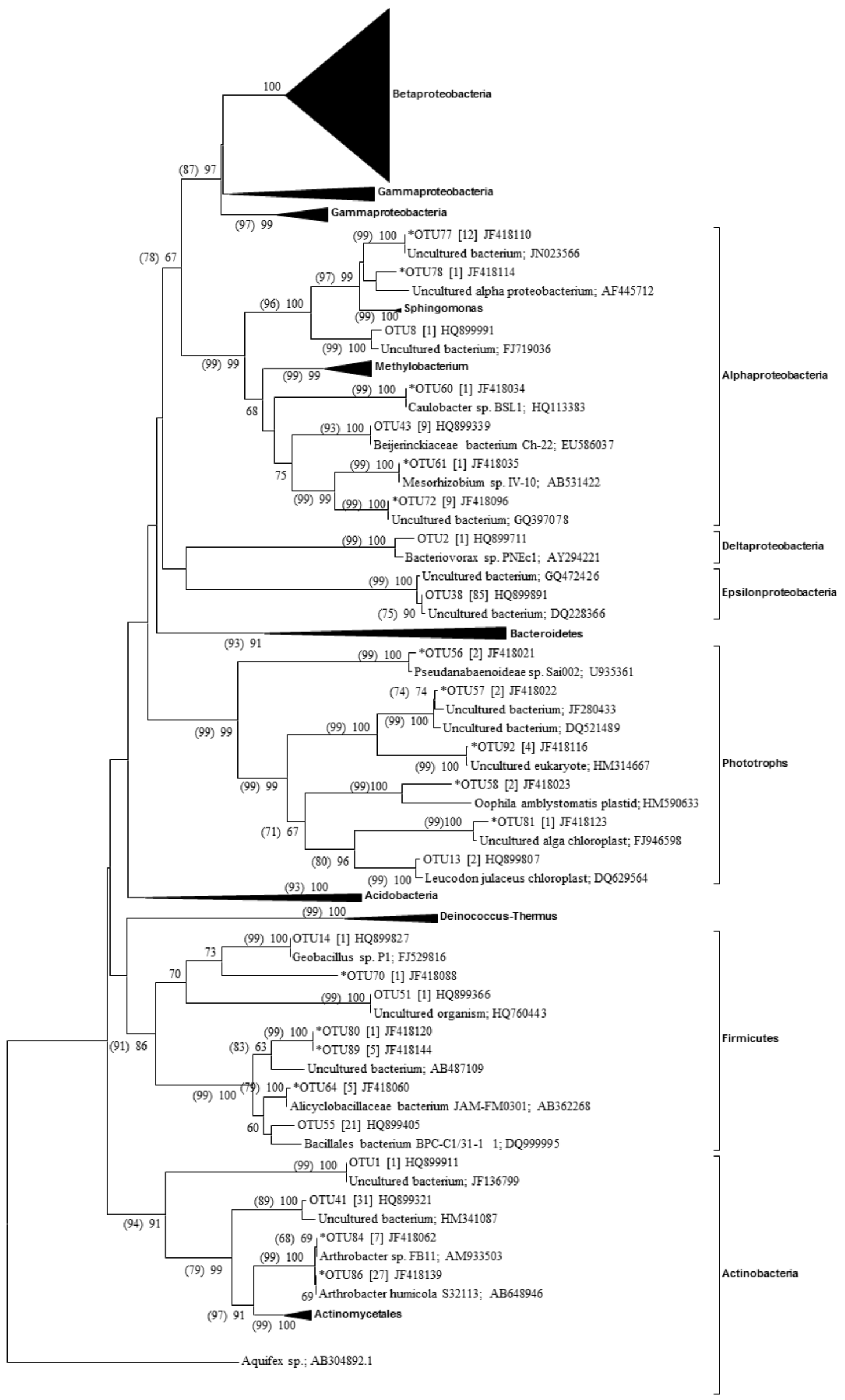


Figure 5 (b)

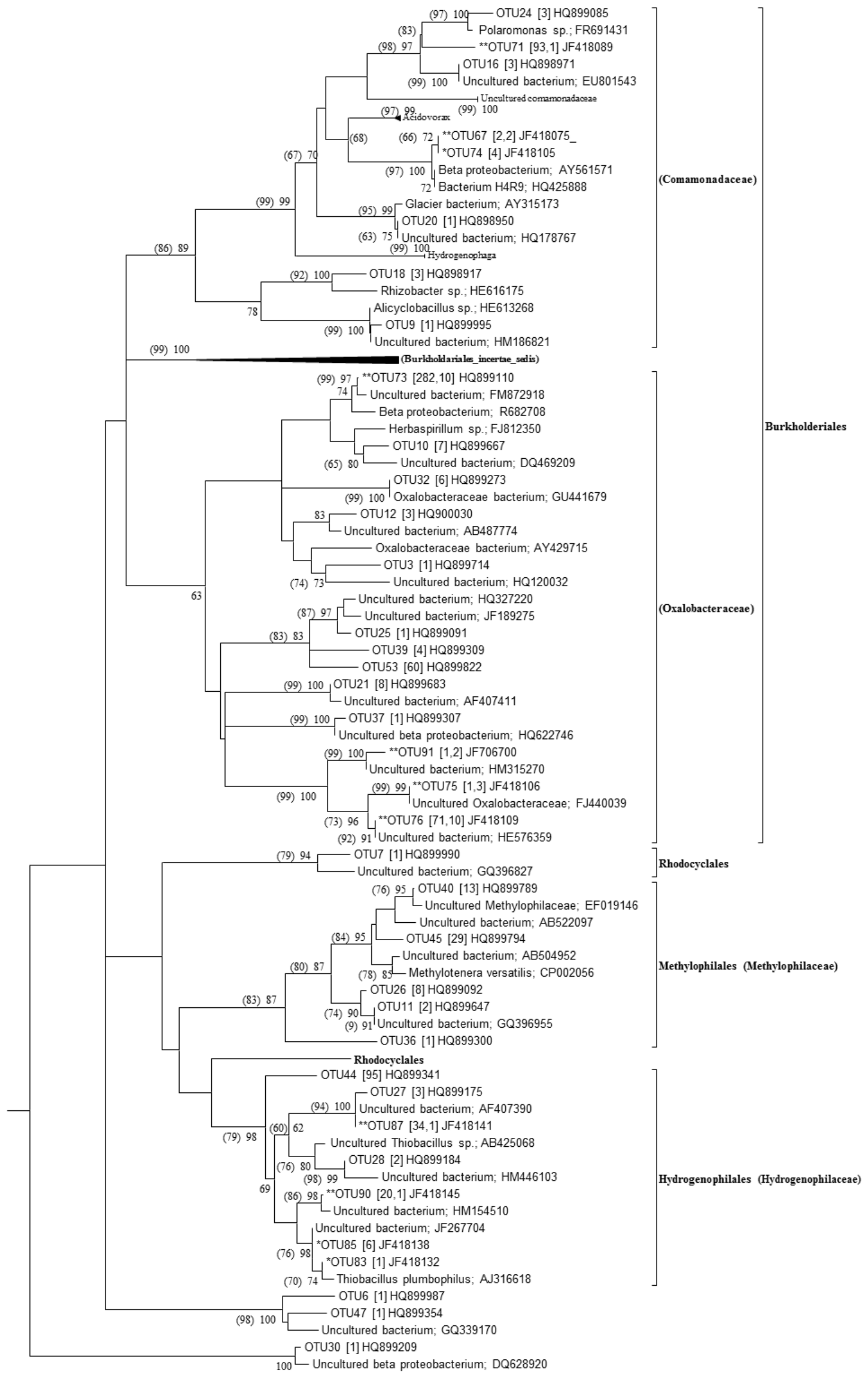

